\title{
A COMPARATIVE STUDY TO EVALUATE THREE IMPORTANT PLANT OILS FOUND IN EGYPT
}

\author{
M.M.D. Shabana, M. M. Abozid, S. A. El-Kadousy and F. M. El-Shuony \\ Biochemistry department, Faculty of Agriculture, Menoufia University.
}

Received: Jan. 17, 2019

Accepted: Jan. 23,2019

\begin{abstract}
Oils are a very important component in different diets, which makes it important for researchers to constantly search for a variety of sources of these oils that are acceptable to consumers on the one hand and are characterized by high nutritional value and storage properties on the other hand. This study was carried out to determine physical properties of linseed, soybean and walnut oils (Refractive index, color, specific gravity) as well as chemical properties (Acid value, saponification value, ester value, iodine value and peroxide value). The percentage of unsaponifiable matter and stability induction period at $100 . \mathrm{C}$ were also estimated. To determine the nutritional value of these oils, both their fatty acid content (assessed by the gas chromatography apparatus) and sterol content (assessed by GC-MS). Physical properties of linseed, soybean or walnut oils showed that; refractive index were 1.48, 1.47 and 1.84, respectively, while color (red) intensity were 9.5, 3.5 and 2.6, respectively and specific gravity were $0.93,0.92$ and 0.92, respectively. On the other hand, chemical properties of linseed, soybean or walnut oils showed that; saponification value were 192, 191 and 190.73(mg KOH/g oil), respectively, while acid value were $0.87,0.27$ and 0.79 ( $\mathrm{mg} \mathrm{KOH} / \mathrm{g}$ oil), respectively, and iodine value were 175, 128 and 145 (g $I_{2} / 100 \mathrm{~g}$ oil), respectively, finally, peroxide value were 1.95, 0.77 and 1.31 (Meq oxygen/Kg), respectively. Alpha linolenic acid was the major fatty acid in linseed oil (60.21\%), while linoleic acid was the main fatty acid in both, soybean oil (52.83\%) and walnut oil (61.85\%). $\beta$-sitosterol was the main sterol in the linseed, soybean or walnut oils (54.72, 40.13 and $76.85 \%$, respectively). As shown by the results, the three studied oils showed high content of essential fatty acids, (both omega3 and omega-6), making them promising oils to support diets with essential fatty acids.
\end{abstract}

Key words: Alpha- linolenic acid, linoleic acid, linseed oil, soybean oil, walnut oil, Physical properties and chemical properties of oils, sterols.

\section{INTRODUCTION}

National Heart Association has recommended increasing consumption of fatty fish or omega-3 polyunsaturated fatty acids (PUFAs) supplements to prevent CVD. Non- fish sources of omega-3 PUFAs vary in their capacity to regulate blood levels of eicosapentaenoic acid (EPA), docosahexaenoic acid (DHA) (C20, 22, omega-3 PUFAs) and CVD risk factors (Jump et al., 2012). Therefore, many studies have been conducted to verify the effectiveness of certain foods in the prevention of these cardiovascular diseases (De Miranda et al., 2014). On the other hand, high omega-3/omega- 6 ratio, promote the pathogensis of cardiovascular diseases (Simopoulos, 2008). Meanwhile, omega-3 fatty acids can improve arterial and endothelial function and decrease the risk of thrombosis (Kris-Etherton et al., 2003). Effects of different types of PUFAs on body adiposity are controversial. However, the issues remain to be elucidated regarding the optimal dosage of omega-3 fatty acids and the ratio of omega-3 to omega- 6 fatty acids (Kromhout et al., 2012).

Linseed oil is the only oil of plant origin known to have the highest concentration of alpha-linolenic acid 
(ALA). Linseed oil has been tested in clinical trials that have described its potential beneficial effect against specific disorders, such as dyslipidemia and cardiovascular diseases (Lemos et al., 2012 and Makni et al., 2008). Soybean is the world's most important legume crop, and the most widely commercialized oilseed growing in different climates worldwide (Pavlova, 1989). Soybean oil is one of the main oils that contains high amounts of monounsaturated and polyunsaturated fatty acids (MUFAs and PUFAs). This specific fatty acid composition helps to reduce blood cholesterol fractions, thus lowering the risk of heart disease. However, soybean oil is highly susceptible to oxidative process (Naz et al., 2005). Among nut oils, walnut oil contains the highest amount of PUFAs (Amaral et al., 2003). The fatty acid composition of walnut oil is unique compared to other nuts oil because walnut oil contains predominantly, linoleic acid (49 to $63 \%$ ), and a considerable amount of ALA (8 to 15.5\%) (Moigradean et al., 2013). Therefore, this study aims to identify the oils of linseed, soyabean and walnut by studying their physical and chemical properties in addition to studying their contents of fatty acids and sterols to discuss the possibility of adding them to the food oils used to improve their properties and health effects.

\section{MATERIALS AND METHODS Materials:}

Linseed (Linum usitatissimum L.), Golden cultivar was obtained from Research Station of Gemiza, Gharbia, Egypt. Soybean (Glycine max L.), Gemiza 111 cultivar was obtained from agriculture research centre, Giza, Egypt. Walnut (Juglans regia L.), was obtained from local market and identified by horticulture department faculty of agriculture, Menoufia University.
Methods:

Extraction of linseed and soybean oils:

The seeds of linseed (Linum usitatissimum L.) and soybean (Glycine $\max L$.) were cleaned and render them free of dust, then oil was obtained by hydraulic piston (model no: 6Y) and subsequently filtrated (filter press).

\section{Extraction of walnut oil:}

Seeds of walnut (Juglans regia L.) were manually cracked and shelled, then milled into a fine powder in an electric mill (Braun, model 1021), and then soaked in pure $\mathrm{n}$-hexane for 24 hours. The mixture were collected and filtered. This process was repeated three times using new solvent each time. The solvent was evaporated under vacuum at $40-45^{\circ} \mathrm{C}$ in rotary evaporator (HAHN SHIN) modelHS-2005-N, under vacuum, made in Korea.

Physical Characteristics of oils:

1- Determination of refractive index:

Refractive index of oil samples was measured using Abbè refractometer (Carl Zeiss JENA, GDR, made in China) at $25^{\circ} \mathrm{C}$ according to the Method of (A.O.A.C. 2000).

2- Determination of color:

A lovibond tintometer (Model F, Visual, made in China) was applied to measure the color using 5.25 inch cell according to the method of the (A.O. C. S. 1989).

3- Determination of Specific Gravity: Specific Gravity of oil samples was measured using a $10-\mathrm{ml}$ automatic gas pycnometer at $30^{\circ} \mathrm{C}$ according to the Method of (A.O.A.C. 2000).

Chemical Characteristics of oils: 1- Determination of Acid value (AV):

Acid value was determined according to (A.O.A.C. 2003). $3 \mathrm{~g}$ of oil were dissolved in $25 \mathrm{ml}$ ethanol; the mixture 
was titrated by $0.1 \mathrm{~N}$ alcoholic potassium hydroxide using phenolphthalein indicator and ‘acid value was calculated as follows:

Acid value (mg $\mathrm{KOH} / \mathrm{g}$ oil) $=\frac{56.1 \times N \times V}{W}$

Where: $\mathrm{N}=$ normality of $\mathrm{KOH} . \quad \mathrm{W}=$ weight of oil in $\mathrm{g}$.

$$
\mathrm{V}=\text { volume }(\mathrm{ml}) \text { of } \mathrm{KOH} \text {. }
$$

56.1 = equivalent weight of $\mathrm{KOH}$.

2- Determination of Saponification value (SV):

Saponification value was determined according to (A.O.A.C. 1995). $5 \mathrm{~g}$ filtered oil was boiled with alcoholic potassium

hydroxide solution (100 $\mathrm{ml}, 0.5 \%)$ for about $30 \mathrm{~min}$. The reaction mixture was cooled down and then titrated with hydrochloric acid solution (0.5 N) using phenolphthalein as an indicator. Another experiment was carried out as a blank without the addition of the oil sample. The calculation was made according to the following equation:

Saponification Value (mg $\mathrm{KOH} / \mathrm{g}$ oil $)=\frac{(\mathrm{B}-\mathrm{S}) \times \mathrm{N} \times 56.1}{\mathrm{~W}}$

Where:

$$
B=\text { volume of }
$$

hydrochloric acid solution $\mathbf{0 . 5}$ $\mathrm{N}$ required by blank.

$$
\mathrm{S}=\text { volume of }
$$

hydrochloric acid solution $\mathbf{0 . 5}$ $\mathrm{N}$ required by oil.

$$
\mathbf{N}=\text { normality of }
$$

hydrochloric acid solution.

56.1= equivalent weight of $\mathrm{KOH}$. W = weight of oil in $\mathbf{g}$.

3- Determination of Ester Value (EV):

The ester value was calc ulated by the following equation according to (A.O.A.C. 2003).

Ester value = (Saponification value - Acid value).

4- Determination of lodine value (IV) (Wijs Method):

The iodine value was determined according to (Singh et al., 1981). $0.25 \mathrm{~g}$ of the oil sample is treated with an excess of iodine bromide $(\mathrm{IBr})$ in glacial acetic acid. Unreacted iodine bromide is reacted with potassium iodide, which converts it to iodine. The iodine concentration is then determined by titration with standard sodium thiosulphate $(0.1 \mathrm{~N})$. lodine value was calculated by using the following equation:

lodine Value ( $\mathrm{gl}_{2} / 100 \mathrm{~g}$ oil) $=\frac{(B-S) \times N \times 127 \times 100}{W \times 1000}$

Where: $\mathrm{B}=$ volume in $\mathrm{ml}$ of $\mathrm{Na}_{2} \mathrm{~S}_{2} \mathrm{O}_{3}$ used in blank. 
$\mathrm{S}=$ volume in $\mathrm{ml}$ of $\mathrm{Na}_{2} \mathrm{~S}_{2} \mathrm{O}_{3}$ used in sample.

$\mathbf{W}=$ weight of oil in $\mathrm{g}$.

127 = equivalent weight of iodine.

5- Determination of Peroxide value $(P V)$ :

Peroxide value was determined according to (A.O.A.C. 1984). $4 \mathrm{~g}$ of oil sample was dissolved in a mixture of acetic acid and chloroform (3:2; v/v) and saturated $\mathrm{KI}$ solution is added to the sample and the amount of iodine liberated from $\mathrm{KI}$ by the oxidative action of peroxides present in the oil is determined by titration with standard sodium thiosulphate using starch solution as an indicator. Titration was also performed for blank's peroxide value. Peroxide value was calculated by using the following equation:

Peroxide value (Meq oxygen $/ \mathrm{kg})=\frac{(\mathrm{S}-\mathrm{B}) \times \mathrm{N} \times \mathbf{1 0 0 0}}{\mathrm{W}}$

Where: B: volume of sodium thiosulphate used in blank.

W: weight of oil in $\mathbf{g}$.

$\mathrm{N}$ : normality of standard sodium thiosulphate.

6- Determination of Oxidative Stability Index:

The oxidative stability index is measured by an accelerated oxidation test using the well established rancimate method. Stability is expressed as the oxidation induction time (hour) which is measured with a Rancimat 679 apparatus (Metrohm Co., Switzerland), using an oil sample of $5 \mathrm{~g}$ warmed to $120^{\circ} \mathrm{C}$, and 20 liters/ hour air flow. The time taken to reach a fixed level of conductivity was measured (Laubli and Bruttel., 1986). This assay was conducted in Oils \& Fats Research Dept., Food Technology Research Institute, Agriculture Research Center, Egypt.

7- Determination of Unsaponifiable Matter (\%): Unsaponifiable matter was determined according to the method described in (A.O.A.C. 2000). A known weight of the oil (ca, 2-2.5g) was dissolved in ethanol (25 $\mathrm{ml}$ ), and then $\mathrm{KOH}$ solution $(10 \% \mathrm{w} / \mathrm{v})$ was added. The oil was saponified on water bath for $30 \mathrm{~min}$ under reflux air condenser. The alcoholic soap solution was quantitatively transferred into separator funnel using a total volume of $50 \mathrm{ml}$ of distilled water and $50 \mathrm{ml}$ of petroleum ether. The unsaponifiable matter was extracted three 
times with petroleum ether, washed several times with distilled water and dried over anhydrous sodium sulphate and then filtered into a weighted flask. The solvent was evaporated using a boiling water bath and the flask was dried at $105^{\circ} \mathrm{C}$ until constant weight was reached. The percentage of unsaponifiable matter was calculated according to the following equation:

$\%$ unsaponifiable matter $=$ weight of the residue/weight of oil $\times 100$

8- Determination and identification of sterols:

The GC-MS analysis of the sterols samples was carried out according to (Soupas et al., 2004) by using gas chromatography- mass spectrometry instrument stands at the Laboratory of medicinal and aromatic plants, National Research Center with the following specifications. Instrument: a TRACE GC Ultra Gas Chromatographs (THERMO Scientific Corp., USA), coupled with a THERMO mass spectrometer detector (ISQ Single Quadrupole Mass Spectrometer). The GC-MS system was equipped with a TR-5MS column (30 $\mathrm{m} \times 0.32$ $\mathrm{mm} \quad$ i.d., $\quad 0.25 \mu \mathrm{mm}$ film thickness). Analyses were carried out using helium as carrier gas at a flow rate of $0.8 \mathrm{~mL} / \mathrm{min}$ at a split ratio of 1:10 and the following temperature program: $50 \mathrm{C}$ for $3 \mathrm{~min}$; rising at $5 \mathrm{C} / \mathrm{min}$ to $300^{\circ} \mathrm{C}$ and held for $15 \mathrm{~min}$. The injector and detector were held at $220^{\circ}$ and $200^{\circ} \mathrm{C}$, respectively. Diluted samples $(1: 10$ hexane, $v / v)$ of $1 \mu \mathrm{L}$ of the mixtures were always injected. Mass spectra were obtained by electron ionization (EI) at $70 \mathrm{eV}$, using a spectral range of $\mathrm{m} / \mathrm{z} 40$ 450. The compounds were identified using mass spectra (authentic chemicals and Wiley spectral library collection).

9- Determination and identification of fatty acids:

Fatty acids analyses of oils were performed by gas chromatography (GC). Samples were transformed into fatty acid methyl esters (FAME) with methanolic boron trifluoride (12\%) methanolic solution and were determined on a gas chromatograph with FID detector (Perkin Elmer Auto System $X L$ ) with auto sampler and Ezchrom integration system. Carrier 
gas (He); ca.25 Psi - air 450 $\mathrm{ml} / \mathrm{min}$ - Hydrogen $45 \mathrm{ml}$ split $100 \mathrm{ml} / \mathrm{min}$. Oven temperature was $200{ }^{\circ} \mathrm{C}$ while for injector and detector it was $250^{\circ} \mathrm{C}$ according to (A.O.A.C. 2012).

Results and Discussion 1- Physical characteristics of linseed, soybean or walnut oils:

Data in Table (1) showed that linseed oil recorded the highest value in both parameters i.e. refractive index and specific gravity (1.49 and 0.93, respectively) followed by walnut oil (1.48 and 0.92 , respectively) while soybean oil showed the lowest values (1.47 and 0.92, respectively). On the other hand, color (red) showed different order; linseed oil was the highest value (9.5) followed by soybean oil (3.5) and finally walnut oil was (2.6).

These results are similar to that of several previous studies conducted on the three types of oils (Rabrenovic et al., 2011;

Tenva et al., 2014; and Uzunovaet al., 2015), which may be explained by the fact that these values reflect the characteristic of physical properties for these types of oils, which do not vary by place of study, but may vary depending on the plant variety used in the experiment.

Table (1): Physical characteristics of linseed, soybean and walnut oils:

\begin{tabular}{|l|c|c|c|}
\hline \multirow{2}{*}{ Physical characteristics } & \multicolumn{3}{|c|}{ Type of oil } \\
\cline { 2 - 4 } & Linseed & Soybean & Walnut \\
\hline Refractive index & 1.49 & 1.47 & 1.48 \\
\hline Color( red) & 9.50 & 3.50 & 2.60 \\
\hline Specific gravity & 0.93 & 0.92 & 0.92 \\
\hline
\end{tabular}

2- Chemical characteristics of linseed, soybean or walnut oils:

Determination of the chemical characteristics of oils gives us an idea about the chemical composition of oils, and so their efficacy to storage process and their validity for use.

Data in Table (2) revealed that linseed oil recorded the highest values for acid value, iodine value and peroxide value $\left(0.87 \mathrm{mg} \mathrm{KOH} / \mathrm{g}\right.$ oil, $175 \mathrm{gl}_{2} / 100 \mathrm{~g}$ oil and $1.95 \mathrm{Meq}$ oxygen $/ \mathrm{kg}$, respectively) followed by walnut oil $(0.79 \mathrm{mg} \mathrm{KOH} / \mathrm{g}$ oil, 
$145 \mathrm{gl}_{2} / 100 \mathrm{~g}$ oil and $1.3 \mathrm{Meq}$ oxygen $/ \mathrm{kg}$, respectively), whilst for soybean oil they were $\left(0.27 \mathrm{mg} \mathrm{KOH} / \mathrm{g}\right.$ oil, $128 \mathrm{gl}_{2} / 100 \mathrm{~g}$ oil and $0.77 \mathrm{Meq}$ oxygen $/ \mathrm{kg}$, respectively).

On the other hand, unsaponifiablematter (\%) showed different order: linseed oil was the highest value $1.03 \%$ followed by soybean oil $\mathbf{0 . 7 8 \%}$ and the lowest one was for walnut oil $0.48 \%$.

Walnut oil also recorded the highest amounts for saponification value and ester value $(194 \mathrm{mg} \mathrm{KOH} / \mathrm{g}$ oil and 193.21 respectively) followed by linseed oil $(192 \mathrm{mg} \mathrm{KOH} / \mathrm{g}$ oil and 191.13 respectively) whereas for soybean oil they were (191mg KOH/g oil and 190.73 respectively).

Finally soybean oil recorded the highest value of stability induction period at $100^{\circ} \mathrm{C},(10.7$ hour) followed by walnut oil (4.86 hour) whilst it was for linseed oil (3.94 hour).

These results are in agreement with those of Rabrenovicet al., (2011) and Viorica-Mirela et al., (2012). The reason of the rapprochement of these values is that they are normal values for these oils at ideal conditions of storage especially acid value, peroxide value and stability induction.

Table (2): Chemical characteristics of linseed, soybean or walnut oils:

\begin{tabular}{|l|l|l|l|}
\hline \multirow{2}{*}{ Chemical Characteristics } & \multicolumn{3}{l|}{ Type of Oil } \\
\cline { 2 - 4 } & Linseed & Soybean & Walnut \\
\hline Acid value (mgKOH/g oil) & 0.87 & 0.27 & 0.79 \\
\hline Saponification value (mg KOH/g oil) & 192 & 191 & 194 \\
\hline Ester Value & 191.13 & 190.73 & 193.21 \\
\hline lodine value (g//2/100g oil) & 175 & 128 & 145 \\
\hline Peroxide value(Meq oxygen/kg) & 1.95 & 0.77 & 1.31 \\
\hline Unsaponifiable Matter (\%) & 1.03 & 0.78 & 0.48 \\
\hline $\begin{array}{l}\text { Stabilityinduction period at } 100^{\circ} \mathrm{C} \text { in } \\
\text { hour }\end{array}$ & 3.94 & 10.7 & 4.86 \\
\hline
\end{tabular}

3- Identification of sterols composition in linseed, soybean or walnut oils (\% of total sterols):

Data in Table (3) indicated that sitosterol was the major sterol in the investigated linseed, soybean or walnut oils, (54.72\%, $40.13 \%$ and $76.85 \%$, respectively) followed by campesterol $(22.60 \%, 24.22 \%$ and $16.11 \%$, respectively) while 
the lowest values were for stigmasterol $(16.01 \%, 21.28 \%$ and $7.04 \%$, respectively), and lanosterol in linseed and soybean oils was, $(6.66 \%$ and $14.36 \%$, respectively) while it was not detected in walnut oil. These results agree with those of Gunstone et al.,(1994); Martinez et al.,(2010) and Tenva et al.,(2014).

Table (3): Identification of sterols composition in linseed, soybean or walnut oils (\% of total sterols)

\begin{tabular}{|l|l|l|l|}
\hline \multirow{2}{*}{ Sterols } & \multicolumn{3}{|l|}{ Type of Oil } \\
\cline { 2 - 4 } & Linseed & Soybean & Walnut \\
\hline B-Sitosterol & 54.72 & 40.13 & 76.85 \\
\hline Campesterol & 22.60 & 24.22 & 16.11 \\
\hline Stigmasterol & 16.01 & 21.28 & 7.04 \\
\hline Lanosterol & 6.66 & 14.36 & ND \\
\hline
\end{tabular}

4.4. Identification of fatty acids composition in linseed, soybean or walnut oils (\% of total fatty acids):

Data in Table (4) stated that linseed oil revealed the highest amount of alpha-linolenic acid (C18:3, omega-3), (60.21\%) followed by walnut oil (12.93\%) and soybean oil (7.12\%) while walnut oil exhibited large amount of linoleic acid (C18:2, omega6), (61.85\%) followed by soybean oil (52.83\%)and linseed oil (14.35\%).

On the other hand, soybean oil recorded the highest percentage of oleic acid (C18:1, omega-9), (22.66\%) followed by walnut oil (14.71\%) and linseed oil (13.49\%).

Data also showed that total saturated / total unsaturated fatty acids ratio was (1:8.93) for walnut oil followed by linseed oil (1:7.70) then it was for soybean oil (1:4.87).

On the other hand the ratio of omega-3 to omega- 6 fatty acids showed the highest level for linseed oil (4.14:1) followed by walnut oil (0.21:1) and soybean oil (0.14:1) at the same trend omega-3: omega-9 ratio recorded the highest level for linseed oil (4.39:1) followed by walnut oil (0.87:1) and soybean oil (0.31:1).

Linseed, soybean or walnut oils showed a high level of total unsaturated fatty acids, reached to over than $80 \%$, also walnut and soybean oils presented a high levels of linoleic 
acid, reached to over than $50 \%$,while linseed oil exhibited over than $60 \%$ of alpha-linolenic acid.

Table (4): Identification of fatty acids composition in linseed,soybean or walnut oils (\% of total fatty acids):

\begin{tabular}{|l|l|l|l|}
\hline \multirow{2}{*}{ Fatty acids } & \multicolumn{2}{l}{ Type of oil } \\
\cline { 2 - 4 } & Linseed & Soybean & Walnut \\
\hline C16:0 & 5.71 & 11.88 & 7.09 \\
\hline C18:0 & 5.39 & 4.44 & 2.88 \\
\hline C20:0 & 0.17 & 0.36 & 0.09 \\
\hline C22:0 & 0.19 & 0.34 & ND \\
\hline Total saturated F.A & 11.5 & 17.04 & 10.07 \\
\hline C16:1 & 0.07 & 0.05 & 0.08 \\
\hline C18:1 & 13.49 & 22.66 & 14.71 \\
\hline C18:2 omega-6 F.A & 14.35 & 52.83 & 61.85 \\
\hline C18:3 omega-6 F.A & 0.20 & ND & 0.11 \\
\hline C18:3 omega-3 F.A & 60.21 & 7.12 & 12.93 \\
\hline C20:1 & 0.14 & 0.25 & 0.24 \\
\hline $\begin{array}{l}\text { Total unsaturated } \\
\text { F.A }\end{array}$ & 88.5 & 82.96 & 89.93 \\
\hline $\begin{array}{l}\text { Total saturated/Total } \\
\text { unsaturated F.As }\end{array}$ & $1: 7.70$ & $1: 4.87$ & $1: 8.93$ \\
\hline$\sum$ omega-3fatty acids & 60.21 & 7.12 & 12.93 \\
\hline$\sum$ omega-6fatty acids & 14.55 & 52.84 & 61.96 \\
\hline$\sum \omega-9$ fatty acids & 13.73 & 22.96 & 15.03 \\
\hline $\begin{array}{l}\text { omega-3: omega-6 } \\
\text { ratio }\end{array}$ & $4.14: 1$ & $0.14: 1$ & $0.21: 1$ \\
\hline $\begin{array}{l}\text { omega-3: omega-9 } \\
\text { ratio }\end{array}$ & $4.39: 1$ & $0.31: 1$ & $0.87: 1$ \\
\hline
\end{tabular}

These results are parallel with those of Dubois et al., (2007); Harper et al., (2006); Simpolous, (2004); and Tolkachev and Zhuchenko, (2000).

It can be concluded from such results that the three oils are promising sources for essential fatty acids because of the high proportion of essential fatty acids in general (linoleic acid C18:2, omega 6 and alpha-linolenic acid C18:3, omega-3), where these fatty acids play an important role in the synthesis of many vital compounds needed by humans, which requires 
eating with food, In particular, flaxseed oil had a very high content of alpha-linolenic acid (the precursor of other acids in omega-3 family), which necessitates feeding experiments on experimental animals to study its effect on the synthesis of EPA and DHA, which are considered essential steps in the synthesis of Eicosanoids as a prelude to the synthesis of prostaglandins and leukotrienes.

Conclusion

It is possible to deduce the importance of flaxseed, soybean, or walnut oils from the results obtained through this study, whether the physiochemical properties or their content of unsaturated fatty acids and essential fatty acids as well as sterols, which requires further work to evaluate their effect in improving the contents of essential fatty acids especially omega-3 fatty acids when added to diets in experimental animals.

\section{REFERENCES}

Amaral, J. S.; Casel, S.; Pereira, J. A.; Seabra, R. M. and Oliveira, B. P. (2003). Determination of sterol and fatty acid compositions, oxidative stability, and nutritional value of six walnut (Juglansregia L) cultivars grown in Portughal. Journal of Agriculture and Food Chemistry, 51: (7698-7702).

A.O.A.C. (1984). Official Methods of Analysis.Association of Official Analytical Chemists, Washington, DC.

A.O.A.C. (1995). Official Methods of Analysis of the Association of Official Analytical Chemists.Published by the A.O.A.C. $16^{\text {th }}$ Ed. Washington, D.C.

A. O. A. C. (2000). Official Methods of Analysis of the Association of Official Analytical Chemists.Published by the A.O.A.C. International $17^{\text {th }}$ Ed. Washington, D.C.

A. O. A. C. (2003). Official Methods of Analysis of the Association of Official Analytical Chemists.Published by the A.O.A.C. International $\mathbf{1 8}^{\text {th }} \mathrm{Ed}$. Washington, D.C.

A.O.A.C. (2012). Official Methods of Analysis of the Association of Official Analytical Chemists. Published by the A.O.A.C. International $19^{\mathrm{h}}$ Ed. Gaithersburg, Maryland, U.S.A.

A. O. C. S. (1989). Official and Tentative Methods and Recommended Practices of the American Oil Chemists Society, 
$4^{\text {th }}$ edition, Edited by D. Firestone, A.O.C.S, Champaign, IL U.S.A.

De Miranda, A. M.; Ribeiro, G. M.; Cunha, A. C.; Silva, L. S.; dos Santos, R. C. and Pedrosa, M. E. (2014). Hypolipidemic effect of the edible mushroom agarics blazed in rats subjected to ahupercholesterolemic diet. The journal of physiology and Biochemistry, 70: (215-224).

Dubois, V.; Breton, S.; Linder, M.; Fanni, J. and Parmentier, M. (2007). Fatty acid profiles of 80 vegetable oils with regard to their nutritional potential. Eur. J. Lipid Sci. Technol., 109: (710732).

Gunstone, F. D.; Harwood, J. L. and Padley, F. B. (1994). The lipid Handbook, 2nd edn, chapman and Hall, London.

Harper, R.; Edwards, C.; and Jacobson, A. T. (2006). Flaxseed oil supplementation does not affect plasma lipoprotein concentration or particle size in human subjects. J. of Nutrition, 136 (11): (2844- 2848).

Jump, D. B.; Depner, C. M. and Tripathy, S. (2012). Omega-3 fatty acid supplementation and cardiovascular disease. The Journal of Lipid Research, 53: (2525-2545).

Kris-Etherton, P. M.; Harris, W. S. and Appel, L. J. (2003). Omega-3 Fatty Acid and Cardiovascular Disease: New Recommendations From the American Heart Association. Arteriosclerosis, Thrombosis, and Vascular Biology, 23: (151152).

Kromhout, D.; Yasuda , S.; Johanna M.; Geleijinse, J. M. and Shimokawa, H. (2012). Fish oil and omega-e fatty acids in cardiovascular disease: do they really work? European Heart journal, 33: (436-443).

Laubli, M. and Bruttel, P. A. (1986). Determination of the oxidative stability of fats and oils: comparison between the Active Oxygen method and the Rancimat method. Journal of the American Oil Chemist's Society, 63(6): (792-795).

Lemos, J. R. N.; de Alencastro, M. G.; Konrath, A. V.; Cargnin, M. and Manfro, R. C. (2012). Flaxseed oil supplementation decreases C-reactive ptotein levels in chronic hemdialysis patients. Nutriention Research, 32: (921-927).

Makni, M.; Fetoui, H.; Gargouri, N. K.; Garoui, E. M.; Jaber, H.; Makni, J.; Boudawara, T. and zeghal, N. (2008). Hypolipidemic 
and hepatoprotective effects of flax and pumpkin seed mixture rich in $\omega-3$ and $\omega-6$ fatty acids in hypercholestrerolemic rats. Food and Chemical Toxicology, 46: (3714-3720).

Martinez, M. L.; Labuckas, D. O.; Lamarque, A. L. and Maestri, D. M. (2010). Walnut (Juglansnigra L.): genetic resources, chemistry, by-products. Journal Science Food Agriculture, 90 (12): (19591967).

Moigradean, D.; Poiana, M. A.; Alda, L. M. and Gogoasa, I. (2013). Quantitative identification of fatty acid from walnut and coconut oil using GC-MS method. Journal of Aroalimentary Processes and Technologies, 19: (459-463).

Naz, S.; Siddiqi, R.; Sheikh, H. and Sayeed, S.A. (2005). Deterioration of olive, corn and soybean oils due to air, light, heat and deep frying. Food Res Int, 38: (127-134).

Pavlova,N.S.(1989). Fabaceae In Plantae Orientis Extremi. Vol.4.

Leningrad (Rus) van Wyk, B.E. 2005. "Glycine max." Food

Plants of the World: An Illustrated Guide. Portland, OR: Timber

Press. p. 201.

Rabrenovic, B.; Dimic, E.; Maksimovic, M.; Sobajic, S.; and Gajickrstajic, L. (2011). Determination of Fatty Acid and Tocopherol

Compositions and the Oxidative Stability of Walnut (Juglansregia L.)Cultivars Grown in Serbia. Czech J. Food Sci.Vol. 29, No. 1: (74-78).

Simopoulos, A. P. (2004). Omega-3 fatty acids and antioxidants in Edible wild plants. Biol Res 37: (263-277).

Simopoulos, A. P. (2008). The important of the omega-6/omga-3 fatty acid ratio in cardiovascular disease and other chronic disease. Experimental Biology and medicine, 233: (674-688).

Singh, P.R.; Gupta, D.S. and Bajpai, K.S. (1981). In: Experimental Organic Chemistry. Tata McGraw-Hill, 2: 301

Soupas, L.; Juntunen, L.; Lampi, A. and Piironen, V. (2004). Effects of sterol steucture, temperature and lipid medium on phyto sterol oxidation. Journal of Agricultural and food chemistry 52 (21): 6485-6491.

Tenva, O. T.; Zlatanov, M.D.; Antova, G. A.; Angelova-Romova, M.Y. and Marcheva, M. P. (2014). Lipid composition of flaxseeds. Bulgarian Chemical Communications, 46 (3): (465- 472). 
Tolkachev, O. N. and Zhuchenko, A. A. (2000). Biologically active substances of flax: medicinal and nutritional properties (a review). Pharm Chem J., 34: (360-367).

Uzunova, G.; Perifanova-Nemska, M.; Stojanova, M. and Gandev, St. (2015). Chemical composition of walnut oil from fruits on different years old branches. Bulgarian Journal of Agricultural Science, 21 (3): (494-497).

Viorica-Mirela, P.; Gruia, A.; Raba, D.; Dumbrava, D.; Moldovan C.; Bordean, D. and Mateescu, C. (2012). Fatty acids composition and oil characteristics of linseed (LinumUsitatissimum L.) from Romania. Journal of Agroalimentary Processes and Technologies, 18 (2): (136- 


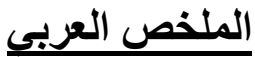

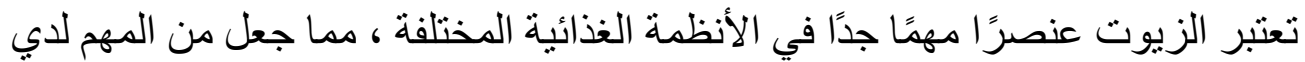

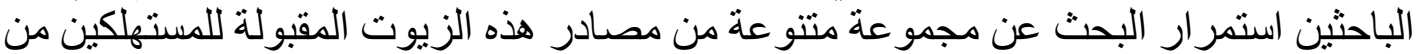

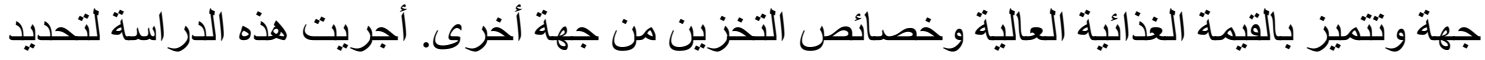

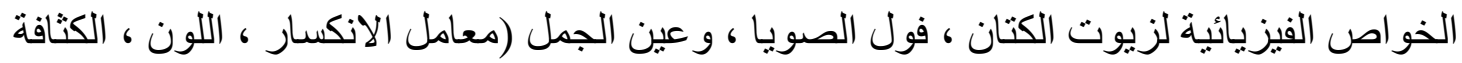

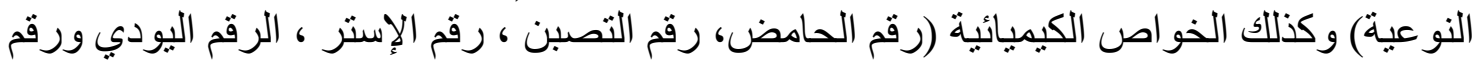

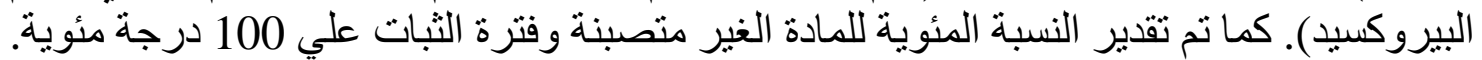

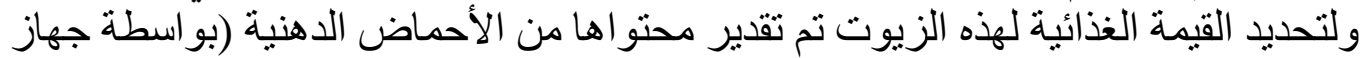

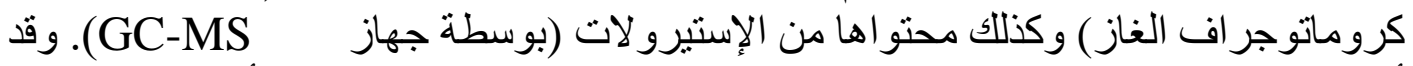

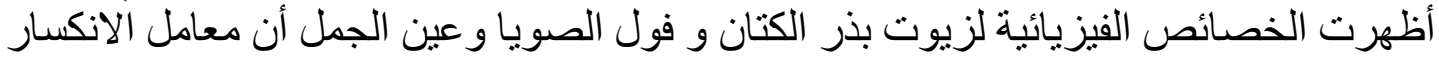

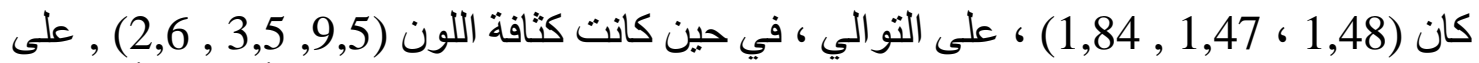

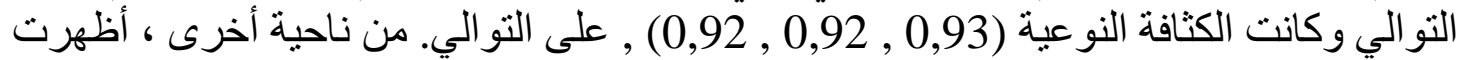

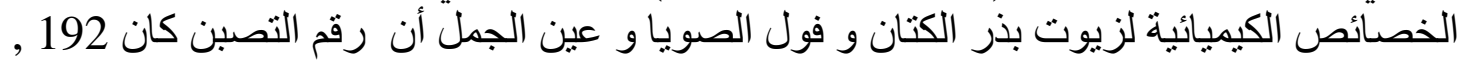

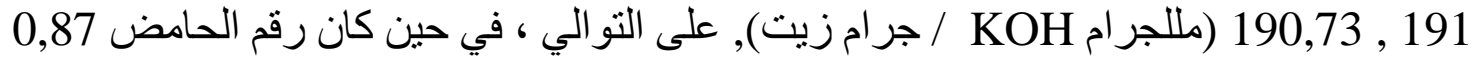
0,79 , 0,27 , 1 , 1 ,

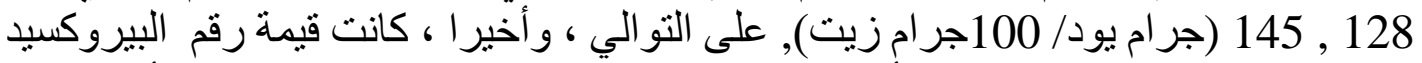

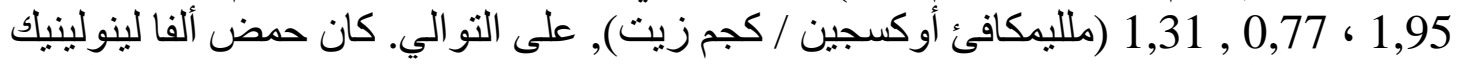
هو الحمض الدهني الرئيسي في زيت بذر الكتان (60,21 \%) ،

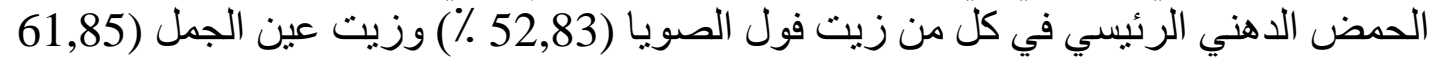

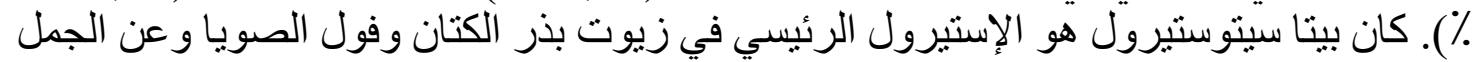

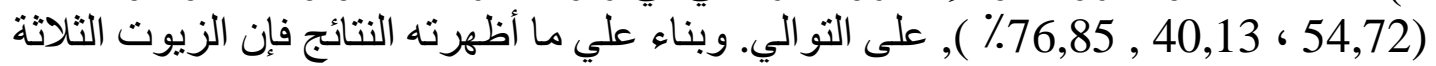

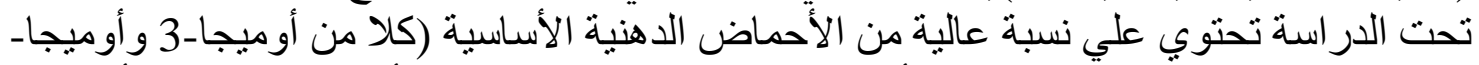
6) ، مما يجعلها زيوت وأعدة لاعم الأنظمة الغذائية التي تحتوي الاضي على الأحماض الدهنة الدنية الأساسية. 